\title{
A case of IgG4 related hypophysitis in a Caucasian female
}

\author{
Hannon A (1), Gupta S (1), Slattery D (1), Mcgurren K (1), Kinsley B (2), Javadpour M (3), Brett F (4), \\ Agha A (1). \\ 1.Department of Diabetes and Endocrinology, Beaumont Hospital, Dublin, Ireland \\ 2. Department of Diabetes and Endocrinology Mater University Hospital, Dublin, Ireland \\ 3. Department of Neurosurgery, Beaumont Hospital, Dublin, Ireland \\ 4. Department of Neuropathology, Beaumont Hospital, Dublin, Ireland
}

\section{INTRODUCTION}

IgG4 related hypophysitis is a recently described entity belonging to the IgG4 related diseases. It is characterised by markedly elevated serum IGG4 levels and tissue infiltration by IgG4 positive plasma cells. To date, 34 cases of IgG4 related hypophysitis have been described but only a handful were in women or biopsy proven.

\section{CASE}

We describe a case of a 58 year old woman who presented with transient headache. She also complained of polyuria and nocturia. She had a thyroidectomy for treatment of hyperthyroidism 10 years previously. MRI pituitary revealed a pituitary mass with marked diffuse stalk thickening. Dynamic evaluation of her anterior pituitary function revealed raised prolactin and severe growth hormone deficiency. An 8-hour water deprivation test showed partial Diabetes insipidus. Ferritin, serum ACE, beta-HCG, alphafetoprotein, autoimmune screen and ANCA were negative. Chest and abdominal imaging and breast mammography showed no malignancy.

A Transsphenoidal pituitary biopsy showed evidence of hypophysitis with fibrosis and increased number of histologically benign plasma cells and $>10$ positive cells per HPF on IgG4 immunocytochemistry which is highly characteristic of IGG-4 related hypophysitis. Her plasma IgG4 level was normal. She was determined to have IgG4 related hypophysitis as per the criteria proposed by Leporati et al in 2011. She was commenced on glucocorticoids and is due for a follow up MRI in 6 months.

\section{DISCUSSION}

IgG4 related hypophysitis is a rare disorder which was first described in 2004 based on clinical data. Whilst there is no definitive criteria to diagnose IgG4 hypophysitis, Leporati et al propsed 5 criteria in 2011; the presence of mononuclear cell infiltrates within the pituitary gland rich in plasma cells and lymphocytes with $>10$ lgG4-positive cells, a sellar mass and/or thickened pituitary stalk, biopsy-proven involvement of other organs with IgG4-positive immunostaining, increased IgG4 serum levels and reduction in sellar mass size and symptom improvement after corticosteroid treatment. However all 5 criteria are not require to make the diagnosis.

IgG4-related diseases are characterised by the infiltration of the target organ with numerous IgG4-producing plasma cells and lymphocytes. IgG 4 is the least abundant of the four IgG antibodies. The antigens recognized by IgG4 antibodies in patients with IgG4-related diseases remain largely unknown.

Of the 34 cases recorded in the literature, 29 were men and 5 were women. The majority of documented cases have been from Japan. While initial case reports were of more severe disease, more recently there have been case reports of patients with milder variants, with one patient reported with normal pituitary function. Accurate diagnosis is essential, as previous reported cases have shown improvement with glucocorticoid therapy.
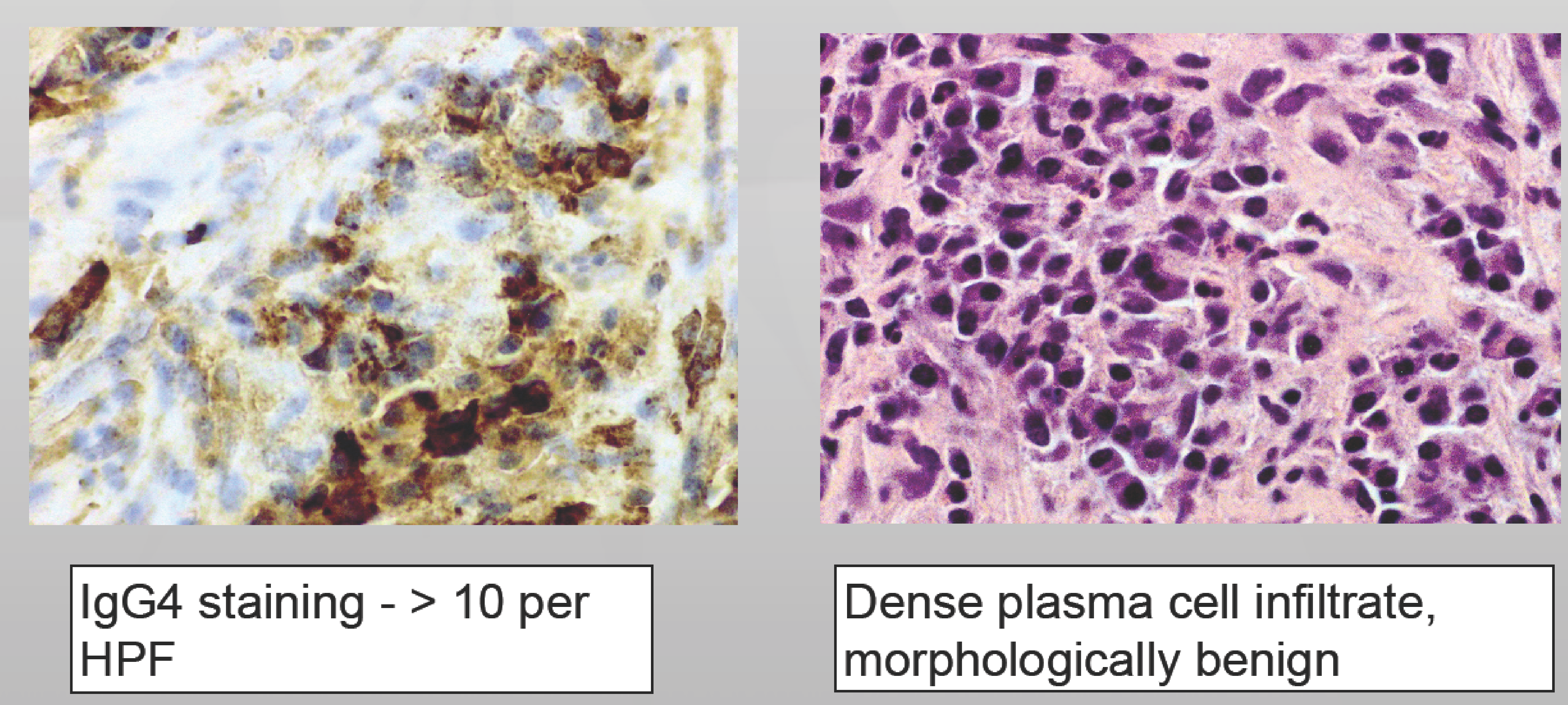

Dense plasma cell infiltrate, morphologically benign
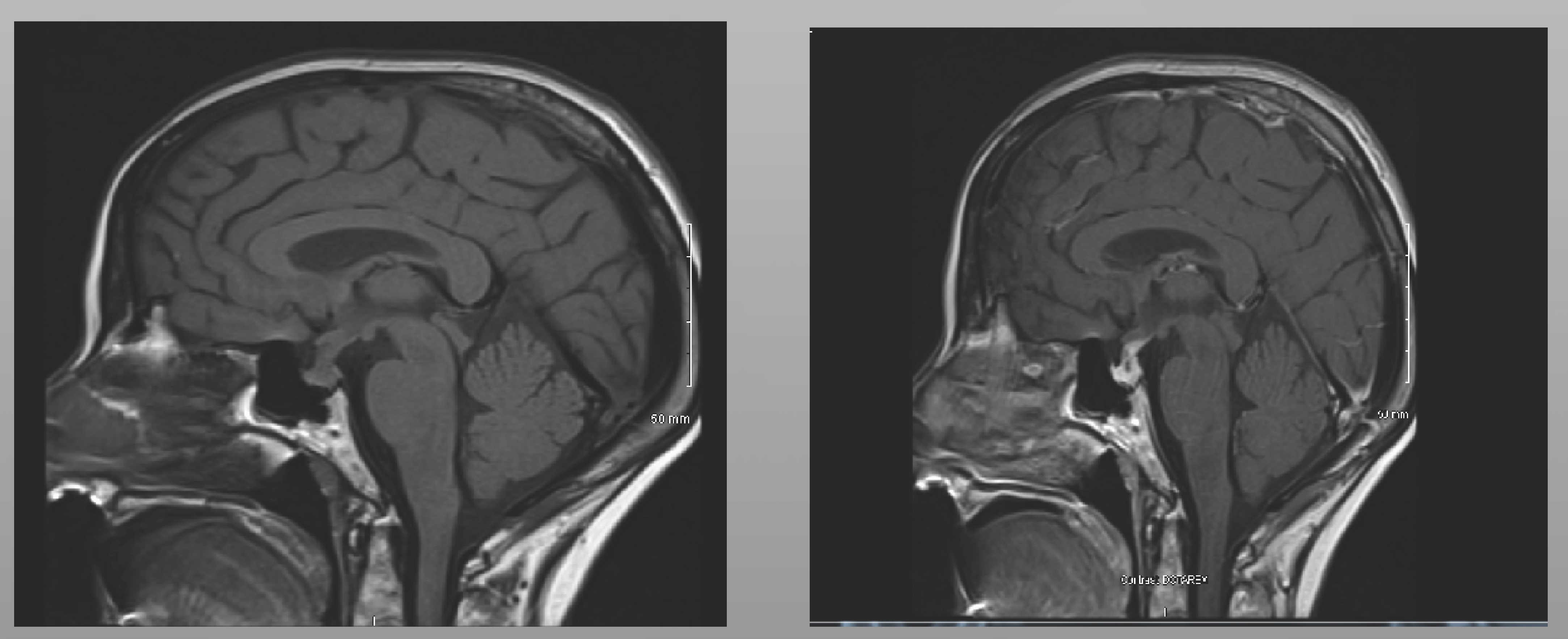

Thickened Pituitary stalk

\begin{tabular}{|c|c|c|c|c|c|}
\hline \multicolumn{6}{|c|}{ Water Deprivation Test } \\
\hline Time (mins) & 0 & 210 & 390 & 450 & 510 \\
\hline $\begin{array}{l}\text { Urinary } \\
\text { Osmolality } \\
(\mathrm{mOsm} / \mathrm{kg})\end{array}$ & 233 & 261 & 406 & 526 & 558 \\
\hline $\begin{array}{l}\text { Serum } \\
\text { Osmolality } \\
(\mathrm{mOsm} / \mathrm{kg})\end{array}$ & 298 & 300 & 299 & 298 & 304 \\
\hline $\begin{array}{l}\text { Serum Na } \\
(\mathrm{mmol} / \mathrm{L})\end{array}$ & 139 & 141 & 141 & 141 & 141 \\
\hline $\begin{array}{l}\text { Urine Output } \\
\text { (ml/hour) }\end{array}$ & 80 & 50 & 40 & 20 & $<20$ \\
\hline
\end{tabular}

\begin{tabular}{|c|c|c|c|}
\hline Time (mins) & $\begin{array}{l}\text { Glucose } \\
(\mathrm{mmol} / \mathrm{L})\end{array}$ & $\begin{array}{l}\text { Cortisol } \\
\text { (nmol/L) }\end{array}$ & $\begin{array}{l}\text { Growth Hormone } \\
\text { (ng/L) }\end{array}$ \\
\hline 0 & 5 & 311 & 0.23 \\
\hline 15 & 1.8 & 267 & 0.11 \\
\hline 30 & 1.3 & 278 & 0.31 \\
\hline 45 & 3.5 & 577 & 0.21 \\
\hline 60 & 3.5 & 560 & 0.28 \\
\hline 90 & 5 & 661 & 0.17 \\
\hline 120 & 6.1 & 547 & 0.11 \\
\hline
\end{tabular}

\section{CONCLUSION}

This case illustrates that when an enlarged pituitary gland/stalk is detected, IgG4 hypophysitis should be considered in the differential diagnosis regardless of pituitary function and serum lgG4 level

\section{REFERENCES}

1. Hamano H, Kawa S, Horiuchi A, Unno H, Furuya N, Akamatsu T, Fukushima M, Nikaido T, Nakayama K, Usuda $\mathrm{N}$ et al. 2001 High serum IgG4 concentrations in patients with sclerosing pancreatitis. New England Journal of Medicine 344 10732-10738 2. Sosa GA, Bell S, Christiansen SB, Pietrani M, Glerean M, Loto M, Lovazzano S, Carrizo A, Ajler P, Fainstein
Day P. Histologically confirmed isolated IgG4-related hypophysitis: two case reports in young women. Endocrino Diabetes Metab Case Rep. 2014;2014:140062. doi: 10.1530/EDM-14-0062.

3. Leporati P, Landek-Salgado MA, Lupi I, Chiovato L \& Caturegli P 2011 IgG4-related hypophysitis: a new addition to the hypophysitis spectrum. Journal of Clinical Endocrinology and Metabolism 96 1971-1980 